\title{
Identifying the Composition of Plant Species and Useful Plants in the Forests of Taman Gumi Banten in Indonesia
}

\author{
NYOMAN WIJANA ${ }^{1, *}$, I MADE OKA RIAWAN ${ }^{1}$, I WAYAN SUKRAWARPALA ${ }^{1}$ \\ ${ }^{1}$ Department of Biology, Fisheries and Marine Sciences, \\ Faculty of Mathematics and Natural Sciences, \\ Ganesha University of Education \\ INDONESIA
}

\begin{abstract}
This study aimed to identify the composition of plant species and Useful plants in the forests of Taman Gumi Banten, Indonesia. This research conducted in the forests of Taman Gumi Banten and village Wanagiri. The population of this study, from the ecosystem aspect, is all plant species in the Taman Gumi Banten forest. From the sociosystem aspect, it is the entire community in Wanagiri village. The sample of this research from the ecosystem aspect is the plant species covered by squares. From the sociosystem aspect, it is a community component. The total sample is 50 people. Data collection methods are quadratic methods and interviews. The sampling technique is a systematic sampling technique. Data were analysed descriptively. The conclusions of this study are (1) There are 68 plant species in the entire forest of Taman Gumi Banten, (2) Of the 68 existing plant species, as many as $59(86.76 \%)$ of the plant species were useful plants, while $9(13.24 \%)$ of them were unknown. (5) The use of plants by the local community is 23 species $(38.98 \%)$ for food, 20 species $(33.89 \%)$ for boards, 9 species $(15.25 \%)$ for medicine, 25 species $(47.17 \%))$ for Hindu religious ceremonies, and industrial materials there are 1 species $(1.69 \%)$.
\end{abstract}

Key-Words: - Composition of Plant Species, Useful Plants, Banten, Wanagiri

Received: April 5, 2021. Revised: November 5, 2021. Accepted: December 5, 2021. Published: January 7, 2022.

\section{Introduction}

Geographically and administratively Wanagiri Village is one of 129 villages in Buleleng Regency and has an area of $1,575 \mathrm{~km} 2$. Topographically, it is located at an altitude of 1,220 meters above sea level (asl). The position of Wanagiri village is hilly which is located in the southern part of Sukasada District, Buleleng Regency. Based on the Decree of the Buleleng Regent Number 430/405 / HK / 2017, regarding the Tourism Village of Buleleng Regency, there are 31 villages designated as tourist villages, one of which is Wanagiri village as a tourist village. What is interesting is that the attractions in Wanagiri Village, Sukasada District are the presence of wild animals, namely long-tailed macaques, which are quite friendly when approached by visiting tourists. This village is surrounded by Tamblingan Lake, thus giving added value to the view that this village has. In addition, this village has quite interesting objects, namely waterfall tourism objects, namely Banyumala waterfall, Banyuwana Amertha waterfall, peak Manik waterfall, and Cemara waterfall [1],[2].
Based on the Decree of the Governor of Bali No. 2017/03-L / HK / 2005 dated 30 October 2015 concerning Village Forest Management Rights (HPHD) granted an area of 30,041 ha managed by Village-Owned Enterprises (BUMDES). For Sawan Sub district, this management grant covers the village of Lemukih village covering an area of 988 ha, Galungan village 712 ha, and Sudaji village 90 ha. Meanwhile, Wanagiri village as one of the villages in the Sukasada District area is entrusted with managing 250 ha of forest [1],[2].

The transfer of forest management from the government to customary villages is intended so that the forest can be used for community welfare, one of which is to support tourism villages. There are several traditional villages planning the forest to be used for tourism objects, on the other hand, there are villages that will use the forest as an intercropping forest. The working area of the village forest in Wanagiri village based on the results of the 2017 simple boundary demarcation is 256.53 hectares and is in a protected forest area. According to the results of spatial data processing of the Land Cover Map in Bali in 2017, the results of land cover are mostly 
still dominated by secondary dry land forest. However, based on observations, in general the condition of land cover in the village forest is almost $80 \%$ in the form of mixed garden stands, and about $20 \%$ is still natural forest. In some places the community carries out land use activities for agricultural and plantation activities. The land cover is quite open, especially in locations that are used for the cultivation of broken flower plants that require full lighting. The location with the densest stand cover is in the forest area of hamlet Bhuana Sari.

Based on observations, the potential for nontimber forest products (HHBK) in the Wanagiri Village Forest area includes types of Multi Purposes Trees Species (MPTS) stands such as jackfruit, candlenut, mangosteen, durian, rattan, bamboo, sapodilla, avocado, sugar palm, coconut. Some of these MPTS stands have only been planted since 2017, to reduce land openness due to planting thousand broken flowers. Meanwhile, for understanding utilization, people generally plant coffee plants with the types of Arabica and Robusta. Generally, the potential of NTFPs is planted in a mixed stand pattern between timber plants, MPTS plants and plantation / agricultural crops [1],[2].

The variety of potential NTFPs in the village forest area (HD) of Wanagiri village includes candlenut, jackfruit, rattan, bamboo palm, durian, mangosteen, avukan, palm oil, coconut and coffee. Especially for coffee plants and thousand broken flowers, apart from inside the Village Forest working area, the people of Wanagiri Village also plant a lot of these commodities outside the area/on owned lands [1],[2].

The Taman Gumi Banten forest, as a part of the forest in Wanagiri village, is in the same condition as other forests in Wanagiri village. Previously, illegal logging had been carried out by irresponsible people. The condition of the forest is very worrying. In 2017, there was also replanting using mahogany plants. The community is allowed to plant coffee, banana, durian and other cultivated plants. In subsequent developments, along with the development of tourist villages, the forest area was designed to be developed into a tourist attraction with special plant characteristics in the form of Banten (offerings, facilities and infrastructure for Hindu religious ceremonies in Bali). Therefore, the forest is called the Taman Gumi Banten forest.

The studies that have been carried out which are analogous to this research are in the villages of Tenganan Pegringsingan, Karangasem Bali, Monkey Forest, Gianyar, Sawan District, Buleleng, Penglipura, Bangli and others. In summary, it is stated that the research supporting this research was conducted in Bali [3]-10]. and outside of Bali [11][16].

The remains of plants in the middle of the village forest, especially in the Taman Gumi Banten forest, after the occurrence of illegal logging and replanting in 2017, there is no data that can be used scientifically related to the existing flora. Likewise, the use of existing plants by the local community is based on the socio-culture of the Wanagiri village community. The results of the research that the authors have done are on reff [7],[17] producing a map of the distribution of rare plant species in the Monkey Forest, Penglipuran, and Alas Kedaton Tourism Forest. The results of the second-year research show that the conservation pattern based on local wisdom is oriented towards awig-awig, myth, religion, tenget (haunted), tonya (resident creatures), and the awareness of the local community. The study conducted by [18] regarding body symbol plants, on medicinal plants show that traditionally in the Balinese Age Tenganan Pegringsingan village, they do not use plant symbolic bodies in pengabenan ceremonies (cremation ceremonies).

The use of plant species in the village of Bali Age Tenganan Pegringsingan does not affect the destruction of the customary forests in the village, the customary forests are still sustainable. This research is also supported by other ethno-botany research such as [19]-[24].

With the description above, it is considered very important in this study with the aim of (1) Knowing the composition of plant species in the forests of Taman Gumi Banten. (2) knowing useful plants in the forest of Taman Gumi Banten.

\section{Materials and Methods}

The implementation of this research can generally be stated that it is located in the village of Wanagiri, Sukasada District, Buleleng Regency, Bali Province. Specifically, the location of this research is in two places, namely in the village of Wanagiri and in the forest of Taman Gumi Banten. In Wanagiri village, it is devoted to collecting data related to data on the use of plants by the community through interviews with the community. Meanwhile, the Taman Gumi Banten forest is related to the collection of plant species composition data.

This research was conducted in the forests of Taman Gumi Banten and village Wanagiri. The population of this study, from the ecosystem aspect, is all plant species in the Taman Gumi Banten forest. From the sociosystem aspect, it is the entire community in Wanagiri village. The sample of this 
research from the ecosystem aspect is the plant species covered by squares. From the sociosystem aspect, it is a community component which. The total sample is 50 people. Data collection methods are quadratic methods and interviews.

In this area of Wanagiri village, there is one forest in the east and north of Wanagiri village which is called the Taman Gumi Banten forest. This forest is a management grant from the central government to the traditional village of Wanagiri. This refers to the Decree of the Governor of Bali No. 2017/03-L / HK / 2005 dated 30 October 2015 concerning Village Forest Management Rights (HPHD) covering an area of 250 ha. The location of this research is clearly presented as shown in Figure 1.

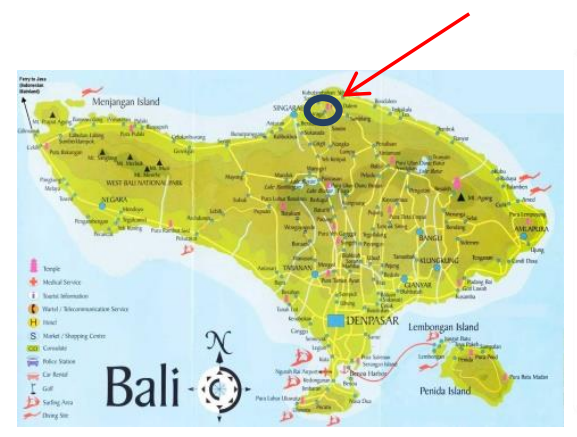

A

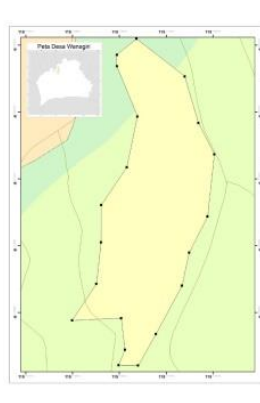

B

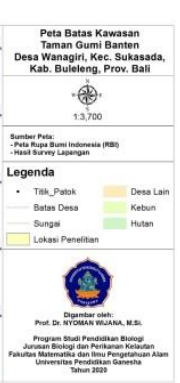

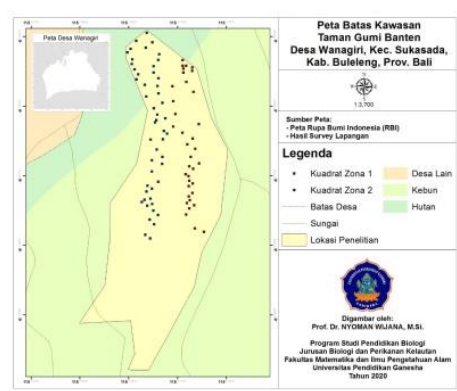

C

Fig. 1: A. Location of Wanagiri Village. B. Location Map of the Taman Gumi Banten Forest. C. Placement of Research Sampling Squares Source: [1].

This type of research is an exploratory research type. This study aims to gather information through exploration in making an inventory of various plant species in the Taman Gumi forest area of Banten. From the results of the exploration and inventory, then a floristic list was compiled, the benefits of plants based on the socio-based community of Wanagiri village, as well as other important information related to this research.

The population of this study consisted of ecosystem (vegetation) and sociocytem aspects. From the ecosystem (vegetation) aspect, the population is all plant species in the forest of Taman Gumi Banten, Wanagiri village. Meanwhile, from the sociosystem aspect, the population is the entire community in Wanagiri village. Research samples from the ecosystem (vegetation) aspect were plant species covered by squares with squared sizes of 20x20 m2, 10x10 m2, and 1x1 m2 each with a total of 86 squares [25]-[29], while samples from the sociosystem aspect were taken from community components such as representatives of official villages, representatives of traditional villages, community leaders, balian / shaman, stakeholders / priests, and the general public. The sample consisted of 50 people. The data collection procedure in this study was divided into two, namely the preparation stage and the implementation stage.

\subsection{Preparation Stage}

The preparation stage in this study, namely:
Observation of Research Sites

1. Observations were made to determine the location, layout, and plant species in the forest of Taman Gumi Banten, Wanagiri village.

2. Prepare permits to carry out research at the Village Office and the the Chairman of the Adat / Kelian Adat.

3. Prepare interview guidelines, questionnaires, and observation sheets, and agree on timing of implementation with the resource persons.

4. Provision of tools and materials to be used in research.

5. Determination of research zones / locations, squares, and sampling techniques for ecosystem aspects

The division of the squares is based on a sampling technique, namely systematic sampling. A systematic approach is usually combined with a transect approach. Systematic sampling technique is chosen because the sampling technique by placing plots / squares / sampling plots is carried out systematically with transect lines that are alternately and continuously positioned on the right and left. This is done so that all plant species in each location can be recorded [25]-[29].

The sampling method uses multiple plot methods. This method is done by placing a plot of a certain size which is done repeatedly. The square size in this study is based on habitus, namely matures / trees with a square size of $20 \times 20 \mathrm{~m} 2$. The tree category is mature plants having a diameter of 
$20 \mathrm{~cm}$, with this square size also includes the square size for saplings (saplings, poles) with a squared size of $10 \times 10 \mathrm{~m} 2$, plants with a diameter of $10 \mathrm{~cm}$ to $20 \mathrm{~cm}$, and seedlings (seedlings). / understorey) with a square size of $1 \times 1 \mathrm{~m} 2$, namely regeneration plants from sprouts to tillers measuring less than 1.5 $\mathrm{m}$ tall [25]-[29]. Determination of the zone / location in this study is in Taman Gumi Banten with squared placement as in Figure $1 \mathrm{C}$.

\subsection{Implementation Stage}

Ecosystem aspects. The implementation stage on the topic of ecosystem aspects is the stage in data collection. This stage is divided using two methods, namely the method of observation and interviews. The observation method is used to obtain data related to ecosystem aspects, while interviews are used to obtain data related to sociosystem aspects. Field observations (in the Taman Gumi Banten forest) by applying the plot method (Plot Method) with a systematic sampling technique [25]-[29],

The data was collected by counting the number of plants covered by the square. From the results of these observations, then recorded on the observation sheet. Observations for ecosystem aspects include 1) plant species composition 2) number of individual plant species and 3) edaphic and climatic factors. In taking data on the composition of plant species, there are several samples that must be observed carefully, including the name of the plant species (local name, scientific name, and family), the coordinates of the plant's point and the number of individuals of each species. After going through the collection of plant species composition data, then observations are made for the useful plant species that exist in each of these zones. Plant identification was carried out using literature sources such as: [30]-[37] and the results of interviews with local communities and the Bali Province Forestry and Environment Service.

Sociosystem aspects. From the sociosystem aspect, data collection was carried out using the interview method [38]. The data needed from this sociosystem aspect are (1) the area name of the plants collected from field observations, (2) the use of plants according to the culture of the local community and (3) other interviews related to the necessary supporting data. In this interview, the interview guide, questionnaire and check list were used.

\section{Results}

It should be stated that the study area is divided into 2 zones, namely zone I and zone II. The number of squares in zone I is 36 squared, while in zone II the squares are stretched as much as 50 squares. So that the total squared is 86 squared. Zone I is in the eastern part of the forest area of Taman Gumi Banten, while zone II is in the western part. The sample area for zone $\mathrm{I}$ is $20 \times 20 \times 36=14,400 \mathrm{~m} 2$ for data collection on tree species. For the data collection of plant species, the sapling category was $10 \times 10 \times 36=3600 \mathrm{~m} 2$. The sampling area for the seedling category is $1 \times 1 \times 36=36 \mathrm{~m} 2$. The sampling area in zone II for the category of plant species belonging to the tree group is $20 \times 20 \times 50=20000$ $\mathrm{m} 2$. The sampling area for the sapling category is $10 \times 10 \times 50=5000 \mathrm{~m} 2$. For the seedling category, the area is $1 \times 1 \times 50=50 \mathrm{~m} 2$. The total sampling area for zones I and II is 20x20) x86 + (10x10)x86+ $(1 \times 1) \times 86=43086 \mathrm{~m} 2$. A recapitulation of plant species in the Taman Gumi Banten Forest is presented in detail in a floristic list as shown in Table 1.

Referring to the data presented in Table 1, it is presented that there are as many as 68 plant species found in the forest of Taman Gumi Banten, with the number of individual plant species belonging to the tree, sapling and seedling categories obtained as many as 1,501 individuals. The area squared used is $(20 \times 20 \times 86)+(10 \times 10 \times 86)+(1 \times 1 \times 86)=43.086 \mathrm{~m} 2$. So the sampling area is $43,086 \mathrm{~m} 2$. Based on the number of existing individuals with a certain unit area, one square meter is $0.034837302 / \mathrm{m} 2$. Furthermore, the number of individuals is calculated in hectares and the amount is 348,373 / ha. Thus, the number of individual species in the tree, sapling, and seedling categories was 348 individuals / ha. Based on the number of individuals present, it seems that the plant species that characterize the forest vegetation of the Taman Gumi Banten are banana, Arabica coffee, Robusta coffee, and yehyeh. The banana, Arabica coffee, and Robusta coffee are cultivated plants, while yeh-yeh are wild shrubs. 
Table 1. Composition of Plant Species in the Taman Gumi Banten Forest, Wanagiri Village

\begin{tabular}{|c|c|c|c|c|}
\hline No & Family & Scientific Name & Local Name & Number of individuals \\
\hline 1 & & Trema orientalis & Lenggung & 23 \\
\hline 2 & & Erythrina variegata $L$ & Kayu Sakti & 34 \\
\hline 3 & & Blumea balsamifera & Sembung & 23 \\
\hline 4 & & Homolanthus giganteus & Belantih & 56 \\
\hline 5 & & Dysoxylum densiflorum & Majegau & 27 \\
\hline 6 & & Eusideroxylon zwageri & Kayu Besi & 5 \\
\hline 7 & & Artocarpus heterophyllus & Nangka & 8 \\
\hline 8 & & Toona sureni & Suren & 4 \\
\hline 9 & & Cinnamomum verum & Kayu Manis & 4 \\
\hline 10 & & Hibiscus sp. & Lemasih & 23 \\
\hline 11 & & Aquilaria malaccensis & Gaharu & 18 \\
\hline 12 & & Swietenia mahagoni & Mahoni & 21 \\
\hline 13 & & Ficus sp. & $\mathrm{Ae}$ & 35 \\
\hline 14 & & Eugenia operculata & Kayu Batu & 5 \\
\hline 15 & & Bischofia javanica & Gintungan & 20 \\
\hline 16 & & Eugenia densiflora & Kaliampuak & 5 \\
\hline 17 & & Savravia nudifora & Yeh-yeh & 155 \\
\hline 18 & & Planchonia valida & Kutat & 13 \\
\hline 19 & & Chromolaena odorata & Kirinyuh & 35 \\
\hline 20 & & Dendrocnide stimulasns & Lateng Kidang & 37 \\
\hline 21 & & Spatholobus littoralis hassk & Bajakah & 44 \\
\hline 22 & & Ficus glabela & Bunut & 4 \\
\hline 23 & & Pterospermum javanicum & Bayur & 11 \\
\hline 24 & & & Udu & 8 \\
\hline 25 & & Michelia alba & Cempaka Putih & 9 \\
\hline 26 & & Pangium edule & Tangi & 4 \\
\hline 27 & & & Kresek & 9 \\
\hline 28 & & Artocarpus elastica & Taep & 4 \\
\hline 29 & & Guazuma ulmifolia & Jati Belanda & 3 \\
\hline 30 & & Ficus benjamina & Beringin & 2 \\
\hline 31 & & Gracinia celebica & Paradah & 47 \\
\hline 32 & & Stelechocarpus burahol & Kepelan & 1 \\
\hline 33 & & Ficus fistulosa & Dadem & 12 \\
\hline 34 & & Musa paradisiaca & Pisang & 187 \\
\hline 35 & & Krema laurina wrab & Kayu Jeleme & 1 \\
\hline 36 & & & Kebasih & 5 \\
\hline 37 & & Averrhoa carambola & Belimbing & 1 \\
\hline 38 & & Persea americana & Alpukat & 62 \\
\hline 39 & & Syzygium aromaticum & Cengkeh & 1 \\
\hline 40 & & Coffea arabica & Kopi Arabika & 147 \\
\hline 41 & & Coffea canephora & Kopi Robusta & 135 \\
\hline 42 & & Capsicum frutescens & Cabai & 24 \\
\hline 43 & & Durio zibethinus & Durian & 19 \\
\hline 44 & & Garcinia mangostana & Manggis & 2 \\
\hline 45 & & Codiaeum variegatum & Talas / Keladi & 12 \\
\hline 46 & & Salacca edulis & Penyalin & 3 \\
\hline 47 & & Salacca edulis & Salak & 1 \\
\hline 48 & & Symplocos thelfolia & Pamor & 3 \\
\hline 49 & & Baccaurea racemosa & Kepundung & 3 \\
\hline 50 & & Ficus carica & Ara & 8 \\
\hline 51 & & Alstonia Scholaris & Pule & 6 \\
\hline 52 & & Syzygium polyanthum & Janggar Ulam & 5 \\
\hline 53 & & Toxicodendron vernicifluum & Laka & 5 \\
\hline
\end{tabular}




\begin{tabular}{|c|c|}
\hline 54 & Terminalia sumatrana Mic \\
\hline 55 & Cordyline frucitosa \\
\hline 56 & Cordyline terminalis \\
\hline 57 & Etlingera elatior \\
\hline 58 & Syzygium cumini \\
\hline 59 & Eusideroxylon zwageri \\
\hline 60 & Mangifera indica \\
\hline 61 & Ardisia elliptica \\
\hline 62 & Solanum quitoebse \\
\hline 63 & Pteridium aquilinun \\
\hline 64 & Solanum torvum \\
\hline 65 & Nymphaea sp. \\
\hline 66 & Codiaeum variegatum \\
\hline 67 & Manihot esculenta \\
\hline 68 & Cocos nucifera \\
\hline
\end{tabular}

Table 1 indicates there are as many as 68 plant species found in the forest of Taman Gumi Banten, with the number of individual plant species belonging to the tree, sapling and seedling categories obtained as many as 1,501 individuals. The area squared used is $(20 \times 20 \times 86)+(10 \times 10 \times 86)$ $+(1 \times 1 \times 86)=43.086 \mathrm{~m} 2$. So the sampling area is $43,086 \mathrm{~m} 2$. Based on the number of existing individuals with a certain unit area, one square meter is $0.034837302 / \mathrm{m} 2$. Furthermore, the number of individuals is calculated in hectares and the amount is 348,373 / ha. Thus, the number of individual species in the tree, sapling, and seedling categories was 348 individuals / ha. Based on the number of individuals present, it seems that the plant species that characterize the forest vegetation of the Taman Gumi Banten are banana, Arabica coffee, robusta coffee, and yeh-yeh. Banana, Arabica coffee, and Robusta coffee are cultivated plants, while yeh-yeh are wild shrubs.

$\begin{array}{lc}\text { Kayu Kunyit } & 2 \\ \text { Andong Hijau } & 12 \\ \text { Andong Merah } & 10 \\ \text { Bongkot } & 23 \\ \text { Juwet } & 1 \\ \text { Kayu Besi } & 5 \\ \text { Mangga } & 7 \\ \text { Lampeni } & 2 \\ \text { Terong Bangkung } & 14 \\ \text { Pakis } & 49 \\ \text { Terong Pokak } & 20 \\ \text { Teratai Darat } & 12 \\ \text { Puring } & 3 \\ \text { Singkong } & 1 \\ \text { Kelapa } & 1 \\ & 1,501\end{array}$

Based on the existing provisions, that the minimum number of individual plant species in one hectare is 1,000 trees / ha [39][40], or according to an interview with one of the officers from the Bali Provincial Environment and Forestry Service) is 700 / Ha. Based on these provisions, the condition of the forest in terms of the number of individuals is in the medium category $(348<700<1,000)$.

Based on the number of individual species present, it can be seen that the four species of plants that are quite prominent with the largest number of individuals are banana, yeh-yeh, Arabica coffee and Robusta coffee. Banana, Arabica and Robusta coffee are cultivated plants, while the yeh-yeh plants are wild shrubs. Based on this, it can be interpreted that in the forest area of Taman Gumi Banten, it is indicated that there has been human or community intervention in carrying out activities in the forest.

Based on the results of interviews with local villagers, the number of useful plant species in the Taman Gumi Banten Forest, Wanagiri Village is presented in Table 2.

Table 2. Useful Plant Species in the Taman Gumi Banten Forest, Wanagiri Village

\begin{tabular}{|c|c|c|c|c|c|c|c|}
\hline \multirow{2}{*}{ No } & \multirow{2}{*}{ Species } & \multirow{2}{*}{ Scientific Name } & \multicolumn{5}{|c|}{ Type Of Utilization } \\
\hline & & & $\mathrm{Sd}$ & $\mathrm{Pg}$ & $\mathrm{Pp}$ & $\mathrm{Ob}$ & Up In \\
\hline 1 & Lenggung & Trema orientalis & & & $\sqrt{ }$ & & \\
\hline 2 & Kayu Sakti & Erythrina variegata $L$ & & & & & $\sqrt{ }$ \\
\hline 3 & Kayu Sembung & Blumea balsamifera & & & & $\sqrt{ }$ & \\
\hline 4 & Belantih & Homolanthus giganteus & & & $\sqrt{ }$ & & \\
\hline 5 & Majegau & Dysoxylum densiflorum & & & & & $\sqrt{ }$ \\
\hline 6 & Kayu Besi & Eusideroxylon zwageri & & & $\sqrt{ }$ & & \\
\hline 7 & Nangka & Artocarpus heterophyllus & & $\sqrt{ }$ & & & \\
\hline 8 & Suren & Toona sureni & & & $\sqrt{ }$ & & \\
\hline 9 & Kayu Manis & Cіппатотит verum & & & & $\sqrt{ }$ & \\
\hline 10 & Lemasih & & & & & & \\
\hline 11 & Gaharu & Aquilaria malaccensis & & & & & $\sqrt{ }$ \\
\hline
\end{tabular}




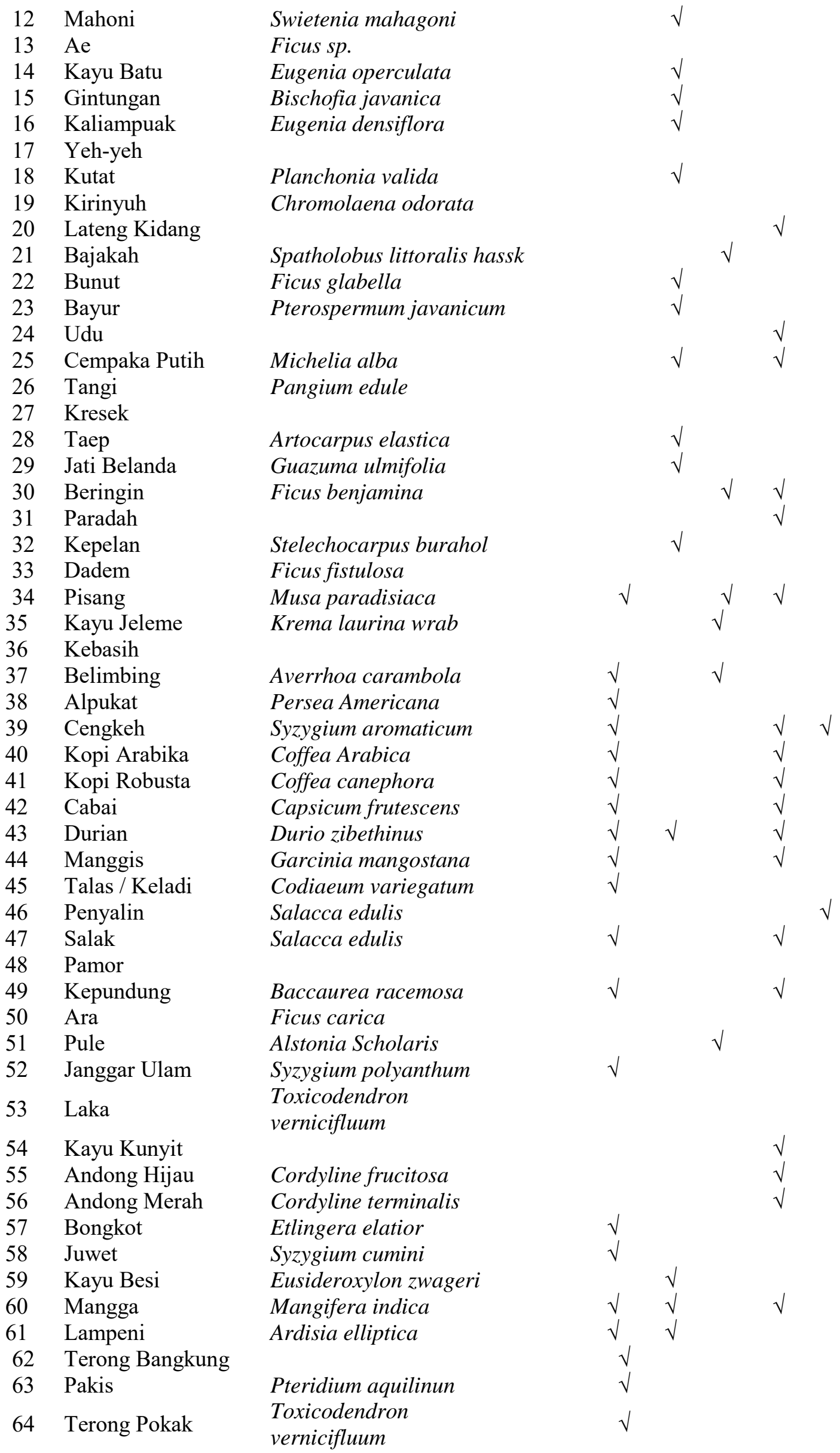




\begin{tabular}{lllllllll}
65 & Teratai Darat & Nymphaea sp. & & & & $\sqrt{ }$ & \\
66 & Puring & Codiaeum variegatum & & & & $\sqrt{ }$ & \\
67 & Singkong & Manihot esculenta & & $\sqrt{ }$ & & & $\sqrt{ }$ & \\
68 & Kelapa & Cocos nucifera & & $\sqrt{ }$ & $\sqrt{ }$ & $\sqrt{ }$ & $\sqrt{ }$ & \\
& TOTAL & & 0 & 23 & 20 & 9 & 25 & 1 \\
\hline
\end{tabular}

Note: $\mathrm{SD}=$ Clothing $\mathrm{Pg}=$ Food $\mathrm{Pp}=$ Board $\mathrm{Ob}=$ Medicine $\mathrm{Up}=$ Religious Ceremony $\mathrm{In}=$ Industry

Table 2 shows there are 68 plant species in the entire squared forest of Taman Gumi Banten, there are $59(86.76 \%)$ plant species of which are useful plants, while 9 (13.24\%) species have not been known for their utilization. The utilization of this plant species is based on the utilization conveyed on reff [32] which is grouped by its uses for clothing, food, shelter, medicine, ceremonies and industry. This research is in line with the results of research conducted by researchers in Bali such as [3]-[16].

Of the 59 species of useful plants or those used by the local community, the details of the utilization are 23 species $(38.98 \%)$ which are useful for food, 20 species $(33.89 \%)$, for boards 9 species $(15.25 \%)$, for medicine. 23 species $(38.98 \%), 25$ species for Hindu religious ceremonies $(47.17 \%)$, and for industrial materials there are 1 species $(1.69 \%)$. Meanwhile, the use of clothing materials is $0 \%$ or none [3]-[16].

After it is known that the use of useful plants is classified, the in-depth study is focused on its use in Hindu religious ceremonies. In the use of useful plants for the benefit of Hindu religious ceremonies, obsession with banten plants. This banten plant is closely related to the socio-culture of the Balinese Hindu community. The Banten plant is a plant used by Balinese people, especially Hindus in making offerings. Banten as a manifestation of the symbolization of human expression in sincerity of worshiping Ida Sang Hyang Widhi Wasa (God
Almighty) and its manifestations. Banten according to the Hindu viewpoint, is not just material, but contains the meaning and philosophy behind the existence of the offering. In the culture of Balinese people who are Hindu, in their activities and interactions in carrying out their religion, they use the facilities and infrastructure of offerings in the form of offerings.

Banten is a means of worshiping and getting closer to Ida Sang Hyang Widhi Wasa and His manifestations adored by His people. Banten is made from various types of material or existing materials, then arranged and arranged in such a way that it is a beautiful offering, has a symbolic function and a deep religious philosophical meaning [41],[42]

Based on Table 1.2, it can be seen that there are 23 species of plants used for Hindu religious ceremonies in Bali, especially in the manufacture of infrastructure and facilities (38.98\%). Utilization of plant species for making Banten infrastructure is quite large. This is inseparable from the culture of the Balinese people, especially those who are Hindu in carrying out religious ceremonies, always accompanied by means of offerings. Based on the use of plants as the infrastructure for making offerings, it is presented in Table 3, which presents the parts / organs of the plants used in making the offerings.

Table 3. Various Species and Plant Organs Used for Construction Infrastructure in Banten

\begin{tabular}{|c|c|c|c|c|c|c|c|c|}
\hline \multirow[t]{2}{*}{ No } & & Species & \multicolumn{6}{|c|}{ Plant Organs } \\
\hline & Local Name & Scientific Name & $\mathrm{a}$ & $\mathrm{b}$ & $\mathrm{c}$ & $\mathrm{d}$ & $\mathrm{E}$ & $\mathrm{f}$ \\
\hline 1 & Kayu Sakti & Erythrina variegata $L$ & & & $\sqrt{ }$ & & & \\
\hline 2 & Majegau & Dysoxylum densiflorum & & $\sqrt{ }$ & & $\sqrt{ }$ & & \\
\hline 3 & Gaharu & Aquilaria malaccensis & & $\sqrt{ }$ & & & & \\
\hline 4 & Lateng Kidang & & & & $\sqrt{ }$ & & & \\
\hline 5 & Udu & & & & $\sqrt{ }$ & & & \\
\hline 6 & Cempaka Putih & Michelia alba & & & & $\sqrt{ }$ & & \\
\hline 7 & Beringin & Ficus benjamina & & & & & & \\
\hline 8 & Paradah & & & & $\sqrt{ }$ & & & \\
\hline 9 & Pisang & Musa paradisiaca & & & $\sqrt{ }$ & $\sqrt{ }$ & $\sqrt{ }$ & \\
\hline 10 & Cengkeh & Syzygium aromaticum & & & & $\sqrt{ }$ & & \\
\hline 11 & Cabai & Capsicum frutescens & & & & & $\sqrt{ }$ & \\
\hline 12 & Durian & Durio zibethinus & & & & & $\sqrt{ }$ & \\
\hline 13 & Manggis & Garcinia mangostana & & & & & $\sqrt{ }$ & \\
\hline
\end{tabular}




\begin{tabular}{lll}
14 & Salak & Salacca edulis \\
15 & Kepundung & Baccaurea racemosa \\
16 & Kayu Kunyit & \\
17 & Andong Hijau & Cordyline frucitosa \\
18 & Andong Merah & Cordyline terminalis \\
19 & Mangga & Mangifera indica \\
20 & Teratai Darat & Nymphaea sp. \\
21 & Puring & Codiaeum variegatum \\
22 & Singkong & Manihot esculenta \\
23 & Kelapa & Cocos nucifera \\
24 & Belimbing & \\
25 & Alpukat & \\
& TOTAL & \\
\hline
\end{tabular}

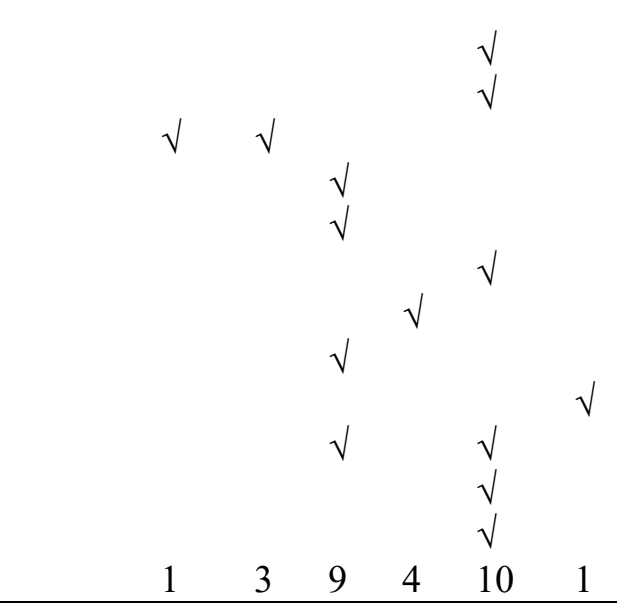

Note: $\mathrm{a}=\operatorname{root} \mathrm{b}=$ stem $\mathrm{c}=$ leaf $\mathrm{d}=$ flower $\mathrm{e}=$ fruit $\mathrm{f}=$ seeds $/$ tubers;

Table 3 displays 25 plants that can be used for the infrastructure for making offerings. Of the 25 species of Banten plants, the body parts or plant organs used were 1 species $(4.00 \%)$ of the roots, 3 species of stems $(12.00 \%), 9$ species of leaves (36.00\%), flowers 4 species $(16.00 \%), 10$ species of fruit $(40.00 \%)$, and 1 species which used the tuber part $(4.00 \%)$. Thus, the most widely used parts of the existing plants in the TamanGumi Banten forest to be used as infrastructure for making offerings are the leaves and fruit.

\section{Discussion}

As the results of data analysis of the existing species composition, especially in terms of the number of individuals, based on existing provisions, that the minimum number of individual plant species in one hectare is 1,000 trees / ha or according to an interview with an officer from the Environment and Forestry Service. Bali Province is 700 / Ha. Based on these provisions, the condition of the forest in terms of the number of individuals is in the medium category $(348<700<1,000)$ (UGM, Simon). This condition is the result of illegal logging carried out by irresponsible people. As previously stated, before forest management was granted to local customary villages, or while it was still managed by the government, illegal logging was rampant. Many trees with large diameter and economic value are cut down. They logged selectively, namely looking for large trees with high economic value. On the other hand, farmers around the forest are planting a thousand broken flower plants in the forest. We know that the broken flower plant requires high lighting. Therefore, a lot of wood or trees are cut down to get a more open space, so that the sunlight can enter fully into the flower plant land [1].

Based on the grouping of illegal logging, the phenomenon that occurs above is a social phenomenon of an individual or a certain group of people. This is in accordance with the opinion expressed on ref [44], namely that there are three types of illegal logging. First, what is done by people or groups of people, either living in the vicinity of the forest or even far from the forest, which do not have legal rights to cut trees. Second, it is carried out by forestry companies that violate the provisions of the permits it owns. The third is done by certain people on behalf of the people.

Data presented by [43] states that the rate of forest destruction in the 1985-1997 period was recorded at 1.6 million hectares per year, while in the 1997-2000 period there was an increase of up to 3.8 million hectares per year. This makes Indonesia one of the places with the highest rates of forest destruction in the world. In Indonesia, based on the interpretation of the Landsat images in 2000, there are 101.73 million hectares of forest and damaged land, of which an area of 59.62 million hectares is in forest areas. The impact caused by illegal logging can be in the form of economic value losses, landslides / floods, loss of fertile soil layers, and reduced water sources [43]. The factors that cause illegal logging, namely lack of personnel. Forestry officials, the availability of employment opportunities and the poverty factor of the people, and the weakness of the legal umbrella [44].

Efforts made by the government include providing forest management grants from the government to customary villages in accordance with the Bali Governor's Decree No. 2017/03-L / HK / 2005 dated 30 October 2015 concerning Village Forest Management Rights (HPHD). In 2017, efforts made by the government were to invite local communities, including traditional villages, to be invited to conserve forests. In that year, replanting was carried out in the Taman Gumi Banten forest. The selected plant is a mahogany plant. The community has been allowed to plant 
coffee and other cultivated crops as intercropping crops. Furthermore, currently forest management has been fully carried out by the local customary village with the person in charge of being a VillageOwned Enterprise (Bumdes).

Along with the development of time, the Taman Gumi Banten forest was designed to become one of the supporting villages for tourism. The forest is developed into a plant center that is intended to support the offering ceremony. Based on this, the forest manager together with traditional villages began adding several types of plants that could be used to support Hindu religious ceremonies, such as banana plants and others. In addition, from the start, coffee plantations have been planted as a result of community intervention before being managed by customary villages. Thus, in terms of species composition, the dominant plants in the Banten Gumi forest are bananas, Arabica coffee, and Robusta coffee [1],[2]. With the management of the Taman Gumi Banten forest by traditional villages, so that forest conservation is maintained, like other customary forests in Bali [3]-[19]. Regarding the use of useful plants, this is in line with the results of research conducted [3]-[19].

\section{Conclusions}

From the results of this study, it can be concluded (1) There are 68 plant species in the entire forest of Taman Gumi Banten, (2) The number of individual species of tree, sapling, and seedling categories is 348 individuals / $\mathrm{Ha}$ which are included in the moderate category. (3) Based on the number of individuals present, plant species that characterize the forest vegetation of Taman Gumi Banten are banana, Arabica coffee, Robusta coffee, and yehyeh. (4) Of the 68 existing plant species, as many as $59(86.76 \%)$ of the plant species were useful plants, while $9(13.24 \%)$ of them were unknown. (5) The use of plants by the local community is 23 species (38.98\%) for food, 20 species $(33.89 \%)$ for boards, 9 species $(15.25 \%)$ for medicine, 25 species $(47.17 \%)$ ) for Hindu religious ceremonies, and for industrial materials there are 1 species $(1.69 \%)$. Meanwhile, the utilization of clothing materials is $0 \%$ or none. (6) there are as many as 25 species of plants that can be used as for making Banten. (7) The body parts or plant organs used were 1 species of roots $(4.00 \%), 3$ species of stems $(12.00 \%), 9$ species of leaves $(36.00 \%), 4$ species of flowers. $(16.00 \%)$, there were 10 species of fruit $(40.00 \%)$, and 1 species used the tuber part $(4.00 \%)$.

\section{Acknowledgments:}

This work was supported in part by the DIPA BLU from the Universitas Pendidikan Ganesha under Grant 631/UN48.16/LT/2021.

\section{References:}

[1]. I. G. Sudirtha, K. Widiartini and M. Suriani, Program Evaluation: Implementation of Tourism Village Development. International Journal of Social Sciences and Humanities, Vol. 3, No. 3, 2019, pp. 99-108.

[2]. P. I. Rahmawati and N. Wijana. Pelatihan Pengembangan Desa Wisata Dan Pendampingan Penataan Homestay Dan Objek Daya Tarik Wisata Di Desa Wanagiri, Kabupaten Buleleng, Bali. In Seminar Nasional Pengabdian Kepada Masyarakat, Vol. 4, 2019, pp. 252-263.

[3]. N. Wijana, and I. G. A. N. Setiawan. Mapping and Distribution of Useful Plant Species in Bukit Kangin Forest, Pegringsingan Village, Karangasem, Bali. In 3rd International Conference on Innovative Research Across Disciplines (ICIRAD 2019), 2020, pp. 87-94.

[4]. N. Wijana, and I. G. A. N. Setiawan. Mapping and Distribution of Useful Plants, Preservation Efforts and Design of Development of Indigenous Forests as Creative Tourism Objects in the Bali Traditional Forest of Tenganan Pegringsingan. Bali Province. Research Report 2019.

[5]. N. Wijana, and I. G. A. N. Setiawan. The utilization of useful plant species based on socio-cultural of Tenganan Pegringsingan Bali Aga village, District of Karangasem, Bali. In Journal of Physics: Conference Series, Vol. 1503, No. 1, 2020, pp. 012042.

[6]. N. Wijana, and I. G. A. N. Setiawan . Distribution and Comparison of Body Symbol (Tri Angga) Species in Bali Age and Bali Majapahit Communities at Trimandala in Bali Province. Research Report. Universitas Pendidikan Ganesha 2018.

[7]. N. Wijana, and I. G. A. N. Setiawan. Plant Species Mapping and Density in The Village Forest of Penglipuran, Bangli, Bali, Indonesia and Its use in Learning Media. International Journal of Natural Science and Engineering, Vol. 1, No. 3, pp. 80-91.

[8]. N. Wijana. Konservasi Tumbuhan Berguna Hutan Bukit Kangin di Desa Adat Tenganan Pegringsingan, Kabupaten Karangasem, Bali. In Seminar Nasional Riset Inovatif, Vol. 7, 2020, pp. 262-275. 
[9]. N. Wijana, I. G. A. N. Setiawan, S. Mulyadiharja, I. G. A. Wesnawa, and P. I. Rahmawati. Environmental Conservation Through Study Value of Bali Aga Tenganan Pegringsingan Community Culture. Media Komunikasi Geografi, Vol. 21 2020, No. 1, pp. 27-39.

[10].N. Wijana. Keanekaragaman spesies tumbuhan, manfaat dan upaya pelestarian oleh masyarakat Desa Adat Tenganan Pegringsingan, Karanga sem. Jurnal Wahana Matematika dan Sains, Vol, 5, No. 10, 2008, pp. 17-34.

[11].J. Iskandar, and B. S. Iskandar, Various plants of traditional rituals: ethnobotanical research among the Baduy community. Biosaintifika: Journal of Biology \& Biology Education, Vol. 9, No. 1, 2019, pp. 114-125.

[12].D. Pare, A. Hilou, N. Ouedraogo, S. Guenne. Ethnobotanical study of medicinal plants used as anti-obesity remedies in the nomad and hunter communities of Burkina Faso. Medicines, Vol. 3No. 2, 2016, pp. 9.

[13].T. Dejene, M. S. Agamy, D. Agúndez, P. Martin-Pinto. Ethnobotanical survey of wild edible fruit tree species in lowland areas of Ethiopia. Forests, Vol. 11, No. 2, 2020, pp. 177.

[14].N. Hasanah. Potential Useful Plants in Yanlappa Nature Reserve, Bogor-West Java (Doctoral dissertation, Thesis. Bogor: Institut Pertanian Bogor) 2011.

[15].E. Ernst, M. H. Cohen, and J. Stone. Ethical problems arising in evidence based complementary and alternative medicine . Journal of Medical Ethics, Vol. 30, No. 2, pp. 156-159.

[16].T. Romeyke, and H. Stummer. Evidence-based complementary and alternative medicine in inpatient care: take a look at Europe. Journal of evidence-based complementary \& alternative medicine, Vol. 20, No. 2, 2015, pp. 87-93.

[17].T. L. Wanadjaja, and P. L. Samputra. Examining tri hita karana as the critic to the triple bottom line of sustainable development. In IOP Conference Series: Earth and Environmental Science, Vol. 716, No. 1, 2021, pp. 012121.

[18].N. Wijana, S. Mulyadiharja, S., and I. M. O. Riawan. Banten Plants and their Mapping in the Taman Gumi Banten Forest, Wanagiri Village, Sukasada-Buleleng. Jurnal Pendidikan Biologi undiksha, Vol. 7, No. 3, 2021, pp. 148163.

[19].I. W. Rasna, N. W. Sariani, I. N. Martha, and G. Artawan. Mantra in Wariga Dalem, Balinese
Traditional Therapy: A Linguistic Anthropology Study. PalArch's Journal of Archaeology of Egypt/Egyptology, Vol. 18, No. 4, 2021, pp. 5545-5565.

[20].L. N. Leurs. Medicinal, aromatic and cosmetic (MAC) plants for community health and biocultural diversity conservation in Bali, Indonesia. Leiden University 2010.

[21].W. Sujarwo, A. P. Keim, V. Savo, P. M. Guarrera, and G. Caneva, G. Ethnobotanical study of Loloh: Traditional herbal drinks from Bali (Indonesia). Journal of Ethnopharmacolo gy, Vol. 169, 2015, pp. 34-48.

[22].K. Ni Wayan, R. Ni Made, and Y. K. P. Gede. Tumpek Uduh Ceremony as an education medium in the preservation of natural environment in Bali: A case study in Canggu Village, Kuta Utara District, Badung Regency, Bali, Indonesia. ASIA LIFE SCIENCES The Asian International Journal of Life Sciences, Vol. 28, No. 1, 2019, pp. 115-139.

[23].W. O. Jumiarni, and O. Komalasari. Inventory of Medicines Plant as Utilized by Muna Tribe in Kota Wuna Settlement. Majalah Obat Tradisional, Vol. 22, No. 1, 2017, pp. 45-56.

[24].J. Sambara, N. N. Yuliani, and M. Y. Emerensiana. Utilization Of Traditional Drug Plant By The People's Community Subdistrict District Of Kupang Timur 2016. Jurnal Info Kesehatan, Vol. 14, No. 1, 2016, pp. 11121125.

[25].F. S. Gilliam, and D. A. Dick. Spatial heterogeneity of soil nutrients and plant species in herb-dominated communities of contrasting land use. Plant Ecology, Vol. 209, No. 1, 2010, pp. 83-94.

[26].P. M. Schiffman. Promotion of exotic weed establishment by endangered giant kangaroo rats (Dipodomys ingens) in a California grassland. Biodiversity \& Conservation, Vol. 3, No. 6, 1994, pp. 524-537.

[27].S. Pigolotti, M. Cencini, D. Molina, and M. A. Muñoz. Stochastic spatial models in ecology: a statistical physics approach. Journal of Statistical Physics, Vol. 172, No. 1, 2018, pp. 44-73.

[28].P. Collen, and R. J. Gibson. The general ecology of beavers (Castor spp.), as related to their influence on stream ecosystems and riparian habitats, and the subsequent effects on fish-a review. Reviews in fish biology and fisheries, Vol. 10, No. 4, 2000, pp. 439-461.

[29].A. M. Liebhold, and J. Gurevitch. Integrating the statistical analysis of spatial data in 
ecology. Ecography, Vol. 25, No. 5, 2002, pp. 553-557.

[30].D. Roth, and G. Sedana. Reframing Tri Hita Karana: From 'Balinese Culture'to Politics. The Asia Pacific Journal of Anthropology, Vol. 16, No. 2, 2015, pp. 157175.

[31].F. Clement, and J. M. Amezaga. Afforestation and forestry land allocation in northern Vietnam: Analysing the gap between policy intentions and outcomes. Land Use Policy, Vol. 26No. 2, 2009, pp. 458-470.

[32].M. Y. Siddiqi, and A. D. Glass. Utilization index: a modified approach to the estimation and comparison of nutrient utilization efficiency in plants. Journal of plant nutrition, Vol. 4, No. 3, 1981, pp. 289-302.

[33].M. Linkie, G. Chapron, D. J. Martyr, J. Holden, and N. I. G. L. Leader Williams. Assessing the viability of tiger subpopulations in a fragmented landscape. Journal of Applied Ecology, Vol. 43, No. 3, 2006, pp. 576-586.

[34].H. Kaskoyo, A. J. Mohammed, M. Inoue. Present state of community forestry (Hutan Kemasyarakatan/HKm) program in a protection forest and its challenges: Case study in Lampung Province, Indonesia. Journal of forest and environmental science, Vol. 30, No. 1, 2014, pp. 15-29.

[35].J. Zhang, Y. Ge, J. Chang, B. Jiang, H. Jiang, C. Peng, and S. Yu. Carbon storage by ecological service forests in Zhejiang Province, subtropical China. Forest Ecology and Management, Vol. 245, No. 1-3, 2007, pp. 6475.

[36].I. W. Suastra. Balinese local wisdom and their implications in science education at school. International Research Journal of Management, IT and Social Sciences, Vol. 4, No. 2, 2017, pp. 48-57.

[37].H. K. Surtikanti, A. Syulasmi, and T. Fatimah. Traditional knowledges of local wisdom of Aga Tenganan Pegringsingan Bali about environmental conservation and sanitation. In Journal of Physics: Conference Series (Vol. 1157, No. 2, 2019, pp. 022117.

[38].M. S. Sumarniasih, and M. Antara. Conservation planning on eroded land based of local wisdom in Kintamani sub-district, province of Bali. In IOP Conference Series: Earth and Environmental Science, Vol. 54, No. 1, 2017, pp. 012010.

[39].D. Parkes, G. Newell, and D. Cheal. Assessing the quality of native vegetation: the "habitat hectares' approach. Ecological Management \& Restoration, Vol. 4, 2003, pp. S29-S38.

[40].K. A. Mir, C. Park, P. Purohit, and S. Kim. Comparative analysis of greenhouse gas emission inventory for Pakistan: Part II agriculture, forestry and other land use and waste. Advances in Climate Change Research, Vol. 12, No. 1, 2021, pp. 132-144.

[41].S. Sharonova, N. Trubnikova, and N. Sokolova. Interpreting religious symbols as basic component of social value formation. European Journal of Science and Theology, Vol. 14, No. 3, 2018, pp. 117-129.

[42].I. Ichwandi, and T. Shinohara. Indigenous practices for use of and managing tropical natural resources: A case study on Baduy community in Banten, Indonesia. Tropics, Vol. 16, No. 2, 2007, pp. 87-102.

[43].L. A. Acosta, E. A. Eugenio, P. B. M. Macandog, D. B. Magcale-Macandog, E. K. H. Lin, E. R. Abucay, and M. G. Primavera. Loss and damage from typhoon-induced floods and landslides in the Philippines: community perceptions on climate impacts and adaptation options. International Journal of Global Warming, Vol. 9, No.1, 2016, pp. 33-65.

[44].K. K. Islam, G. M. Rahman, T. Fujiwara, and N. Sato. People's participation in forest conservation and livelihoods improvement: experience from a forestry project in Bangladesh. International Journal of Biodiversity Science, Ecosystem Services \& Management, Vol. 9, No. 1, 2013, pp. 30-43.

\section{Contribution of Individual Authors to the Creation of a Scientific Article (Ghostwriting Policy)}

Nyoman Wijana writing - original draft, investigation, editing and supervision.

I Made Oka Riawan writing - original draft, investigation, editing and data analysis.

I Wayan Sukrawarpala writing - original draft, investigation, editing and data analysis.

\section{Creative Commons Attribution License 4.0 (Attribution 4.0 International, CC BY 4.0)}

This article is published under the terms of the Creative Commons Attribution License 4.0 https://creativecommons.org/licenses/by/4.0/deed.en US 